\title{
Quantitative Real-Time Polymerase Chain Reaction Assay for Detection of Pectobacterium wasabiae Using YD Repeat Protein Gene-Based Primers
}

\author{
Myeong Ho Kim, Min Seok Cho, Byoung Kyu Kim, Hyeon Jin Choi, Jang Ho Hahn, ChangKug Kim, and Man Jung Kang, Na- \\ tional Academy of Agricultural Science, Rural Development Administration, 441-707 Suwon, Republic of Korea; Seong Hwan Kim, \\ Department of Microbiology, Dankook University, 330-714 Cheonan, Republic of Korea; and Dong Suk Park, National Academy of \\ Agricultural Science, Rural Development Administration, Republic of Korea
}

\begin{abstract}
Kim, M. H., Cho, M. S., Kim, B. K., Choi, H. J., Hahn, J. H., Kim, C., Kang, M. J., Kim, S. H., and Park, D. S. 2012. Quantitative real-time polymerase chain reaction assay for detection of Pectobacterium wasabiae using YD repeat protein gene-based primers. Plant Dis. 96:253-257.

The aim of this study was to develop a quantitative polymerase chain reaction (qPCR) assay for specific detection of Pectobacterium wasabiae using a primer pair based on the YD repeat protein gene for amplification of a 140-bp DNA fragment from infected wasabi (Wasabia japonica), a member of the crucifer family. The soft rot caused by $P$. wasabiae is an emerging disease that is present in many wasabiproducing areas. However, specific and reliable methods for identifying the pathogen are not available. Therefore, a qPCR primer set for accurate diagnosis of $P$. wasabiae was developed from publically available genome sequences. A SYBR Green qPCR primer set was designed

based on a YD repeat protein gene of $P$. wasabiae WPP163 because it is known that this gene is structurally diverse among species, pathovars, or subspecies. The specificity of the primer set was evaluated using genomic DNA from 5 isolates of $P$. wasabiae, 5 different species of Pectobacterium, and 16 other pathogenic reference bacteria. The primer set used in the PCR assay successfully amplified a 140-bp amplicon for all five $P$. wasabiae strains. No amplification was obtained from 29 other pathogenic bacteria. The assay was also able to detect at least two genomic DNA, or 3 CFU per reaction, when using calibrated cell suspension.
\end{abstract}

Wasabi (Wasabia japonica (Miq.) Matsum.), a member of the crucifer family, is one of the popular spices in many Asian countries, especially in Korea and Japan (10). It is currently grown commercially in many countries in the world, including Korea, Japan, New Zealand, Israel, Brazil, Thailand, Taiwan, Canada, and the United States (3). It is a perennial aromatic herb that is cultivated on gravel beds laid in mountain streams at altitudes of about 200 to $800 \mathrm{~m}$ above sea level, where water temperatures range from 10 to $18^{\circ} \mathrm{C}$ during the year $(7,18)$.

Pectobacterium wasabiae $(5,7)$ has a narrow host range, having previously only been associated with Japanese horseradish. However, recent characterization of Pectobacterium spp. causing soft rotting in New Zealand has identified $P$. wasabiae isolates pathogenic to potato (16). The soft rot often occurs when the temperature of irrigation water exceeds $20^{\circ} \mathrm{C}$, because of a decline in water flow during prolonged dry weather conditions, or when gravel beds are muddied by flooding from heavy rains $(7,19)$. The pathogen inhabits rhizome tissues and fibrous roots independently or in a complex without causing bacterial soft rot symptoms as long as the temperature of irrigation water has been maintained below $18^{\circ} \mathrm{C}$ (7). However, there is no report on a specific and reliable method for identifying $P$. wasabiae from the crucifer family in the world thus far. Therefore, it is urgent to establish an accurate, rapid, sensitive, and practical method for detection of the pathogen from wasabi.

Currently, molecular assays based on the 16S-23S rDNA internal transcribed spacer region, $g y r B$, and $r p o D$ are used for the detection of pathogenic bacteria. However, the sequences of these

Corresponding author : D. S. Park, E-mail: dspark@rda.go.kr

* The $\boldsymbol{e}$-Xtra logo stands for "electronic extra" and indicates that a supplemental figure not included in the print edition is available online.

Accepted for publication 10 September 2011.

http://dx.doi.org/10.1094/PDIS-06-11-0511

() 2012 The American Phytopathological Society genes are highly conserved because they differ at only two or three bases with respect to analogous regions in closely related species $(5,12,15)$. However, it has been reported that YD repeat proteins (Rhs repertoires) are ubiquitous and comprise six structurally distinct lineages within the family Enterobacteriaceae, and there is considerable intergenomic variation in $R h s$ repertoires (8). YD repeats proteins are the repetitive dipeptide sequence tyrosineaspartate. They contain two tandem copies of a 21-residue extracellular repeat that is found in gram-negative, gram-positive, and animal proteins. The repeat is named for a YD dipeptide, the most strongly conserved motif of the repeat. These repeats appear in general to be involved in binding carbohydrate. YD repeats may be free on the bacterial surfaces for host interactions as well $(2,13)$.

Therefore, we have investigated the YD repeat protein gene to develop a specific primer set for identifying $P$. wasabiae. The primers will be used to develop a quantitative polymerase chain reaction (qPCR) assay for the quantitative and specific detection of $P$. wasabiae in wasabi, which will allow for the rapid and specific detection of $P$. wasabiae, thereby simplifying diagnosis and monitoring of the pathogen.

\section{Materials and Methods}

Bacterial strains, culture condition, and DNA extraction. Bacterial strains were obtained from the Korean Agricultural Culture Collection in the Republic of Korea and the Belgian Coordinated Collections of Micro-organisms. Bacterial strains used in this study are listed in Table 1. Pectobacterium, Erwinia and Rhizobium strains were incubated on nutrient agar (peptone, $0.5 \% ; \mathrm{NaCl}$, $0.5 \%$; yeast extract, $0.2 \%$; Lab-Lemco beef extract, $0.1 \%$; and agar, $1.5 \%$ ) at $28^{\circ} \mathrm{C}$ for 1 to 2 days; Xanthomonas strains were grown on YGC medium (D-[+]-glucose, $1.0 \%$; $\mathrm{CaCO}_{3}, 3.0 \%$; yeast extract, $0.5 \%$; and agar, $1.5 \%$ ) at $28^{\circ} \mathrm{C}$ for 3 days; and other microbes were grown on Luria-Bertani agar (tryptone, 1\%; yeast extract, $0.5 \%$; sodium chloride, $1 \%$; and agar, $1.5 \%$ ) at 28 to $37^{\circ} \mathrm{C}$ for 1 to 3 days (1). Genomic DNA from bacterial strains was extracted using the bacterial genomic DNA extraction kit supplied by Qiagen (Qiagen, Hilden, Germany). All genomic DNA were quantified using a NanoDrop ND-1000 spectrophotometer (NanoDrop Technologies, Wilmington, DE). 
Primer design and conventional PCR assays. A primer set, PW7011F (5'-CTATGACGCTCGCGGGTTGCTGTT-3') and PW7011R (5'-CGGCGGCGTCGTAGTGGAAAGTC-3'), was designed using PrimerSelect in Lasergene (version 7.2.1; DNASTAR Inc., Madison, WI) for the YD repeat protein gene of $P$. wasabiae WPP163 (GenBank accession CP001790.1, region 385930..390069, protein ID ACX86200.1), with a predicted PCR product of $140 \mathrm{bp}$. The nucleotide sequences of the genes were assessed for specificity and variety among Pectobacterium spp. through BLASTn searches (14). Conventional PCR reactions were carried out with a PTC-225 thermocycler (MJ Research, Watertown, MA). PCR was performed in $50 \mu \mathrm{l}$ of reaction mixture containing $10 \mathrm{mM}$ Tris- $\mathrm{HCl}, 50 \mathrm{mM} \mathrm{KCl}, 1.5 \mathrm{mM} \mathrm{MgCl}_{2}, 0.01 \%$ gelatin, $0.2 \mathrm{mM}$ each dNTP, $20 \mathrm{pM}$ of each primer, 2 units of Taq polymerase (Promega Corp., Madison, WI), and $25 \mathrm{ng}$ of genomic DNA from a given bacterial strains. Reactions were run for 35 cycles, each consisting of $60 \mathrm{~s}$ at $94^{\circ} \mathrm{C}, 30 \mathrm{~s}$ at $67^{\circ} \mathrm{C}$, and $60 \mathrm{~s}$ at $72^{\circ} \mathrm{C}$, with an initial denaturation of $5 \mathrm{~min}$ at $94^{\circ} \mathrm{C}$ and a final extension of $10 \mathrm{~min}$ at $72^{\circ} \mathrm{C}$. Amplified products were separated on $1.5 \%$ agarose gel by electrophoresis at $100 \mathrm{~V}$ for $60 \mathrm{~min}, 1 \times$ Trisacetate-EDTA buffer, then stained with LoadingStar (DYNEBIO, Republic of Korea).

Sensitivity and specificity of the SYBR Green qPCR assay. The SYBR Green qPCR assay was carried out in a $20-\mu l$ reaction mixture containing KAPA SYBR FAST qPCR Master Mix $(2 \times)$ Universal (KAPA Biosystem, Inc.). The amplification mixture consisted of $10 \mu \mathrm{l}$ of KAPA SYBR FAST qPCR Master Mix (2×) Universal and $5 \mathrm{pM}$ each of PW7011F/R and $5 \mathrm{ng}$ of purified DNA from each sample. As for $P$. wasabiae, $5 \mathrm{fg}$ is roughly equivalent to one bacterial genome $(11,17,20)$. Therefore, the bacterial genomic DNA was diluted from $5 \mathrm{ng}$ to $5 \mathrm{fg}$ using 10-fold dilutions.

SYBR Green qPCR assay was performed in the CFX96 realtime PCR system (Bio-Rad Laboratories, Inc.) with the following conditions: $95^{\circ} \mathrm{C}$ for $3 \mathrm{~min}$ and 45 cycles of $95^{\circ} \mathrm{C}$ for $10 \mathrm{~s}, 67^{\circ} \mathrm{C}$ for $20 \mathrm{~s}$, and a melting curve of 65 to $95^{\circ} \mathrm{C}$ with an increment of $0.5^{\circ} \mathrm{C}$. The concentration of the cloned DNA was measured using a fluorometer and the corresponding copy number was calculated using the equation $(4)$ copies $/ \mu \mathrm{l}=\left[6.022 \times 10^{23}(\mathrm{copy} / \mathrm{mol}) \times \mathrm{DNA}\right.$ amount $(\mathrm{g})] /[\mathrm{DNA}$ length $(\mathrm{bp}) \times 660(\mathrm{~g} / \mathrm{mol} / \mathrm{bp})]$.

Detection of pathogen by bio-PCR. For the bio-PCR assay, the pathogen was grown overnight on nutrient agar medium and resuspended in sterile distilled water to an optical density of $600 \mathrm{~nm}$ $\left(\mathrm{OD}_{600}=0.1\right)$. Bacterial suspensions were inoculated by the prick method (7) on independent leaves (W. japonica 'Dalma') of 3year-old healthy plants grown in the greenhouse. Leaf tissue was collected from an area $1 \mathrm{~cm}$ from the inoculation point at 3 days post inoculation, as depicted in Supplementary Figure S1. Each sample was dipped in $500 \mu \mathrm{l}$ of sterile distilled water in a $1.5-\mathrm{ml}$ tube for $30 \mathrm{~min}$. A $2-\mu \mathrm{l}$ sample from the rinse water was directly used in the SYBR Green PCR assays as described above.

\section{Results}

In silico specificity test of designed primer set. Specificity of the primer set $(\mathrm{PW} 7011 \mathrm{~F} / \mathrm{R})$ based on a YD repeat protein (GenBank accession CP001790.1, protein ID ACX86200.1) was tested by similarity search against the sequence database at the National Center for Biotechnology Information (http://www.ncbi.nlm. nih.gov/). When comparing the sequence of the 140-bp fragment amplified by the primer set, the closest match in a BLASTn (version 2.2.25) search revealed only $67 \%$ sequence identity with Pantoea ananatis (GenBank accessions AP012032.1 and CP001875.2). BLAST searches with the predicted protein sequence (BLASTx) revealed that the closest similarity was to the $R h s$ family protein from Enterobacter cloacae subsp. cloacae (American Type Culture Collection 13047, GenBank accession YP_003613625.1) but it only had a maximum identity of $60 \%$. Thus, the sequence region to

Table 1. Bacterial strains used in this study

\begin{tabular}{|c|c|c|c|c|c|}
\hline Number & Scientific name & Source $^{\mathbf{a}}$ & Geographic origin & Host & Assay $^{b}$ \\
\hline 1 & Pectobacterium wasabiae & LMG $8444^{\mathrm{T}}$ & Japan & Japanese horseradish & + \\
\hline 2 & P. wasabiae & KACC 10406 & $\ldots$ & $\ldots$ & + \\
\hline 3 & P. wasabiae & KACC 14078 & Republic of Korea & $\ldots$ & + \\
\hline 4 & P. wasabiae & KACC 10868 & Japan & Japanese horseradish & + \\
\hline 5 & P. wasabiae & KACC 10869 & Japan & Japanese horseradish & + \\
\hline 6 & P. carotovorum subsp. carotovorum & LMG $2404^{\mathrm{T}}$ & Denmark & Schizanthus sp. & - \\
\hline 7 & P. carotovorum subsp. carotovorum & LMG 2399 & United Kingdom & Solanum tuberosum & - \\
\hline 8 & P. carotovorum subsp. carotovorum & LMG 2400 & Japan & Brassica rapa & - \\
\hline 9 & P. carotovorum subsp. carotovorum & LMG 2401 & United States & Daucus carota var. sativus, soft rot & - \\
\hline 10 & P. carotovorum subsp. carotovorum & LMG 2405 & Israel & Persea americana & - \\
\hline 11 & P. carotovorum subsp. carotovorum & LMG 2406 & United Republic of Tanzania & Schizanthus sp. & - \\
\hline 12 & P. carotovorum subsp. carotovorum & KACC 10343 & Republic of Korea & Japanese horseradish & - \\
\hline 13 & P. carotovorum subsp. carotovorum & KACC 10347 & Republic of Korea & Japanese horseradish & - \\
\hline 14 & P. carotovorum subsp. carotovorum & KACC 13968 & Republic of Korea & Potato & - \\
\hline 15 & P. carotovorum subsp. odoriferum & KACC 13954 & Republic of Korea & Chinese cabbage & - \\
\hline 16 & P. atrosepticum & KACC $10477^{\mathrm{T}}$ & United Kingdom & Solanum tuberosum, stem rot & - \\
\hline 17 & P. betavasculorum & LMG $2466^{\mathrm{T}}$ & United States & Beta vulgaris, vascular strand & - \\
\hline 18 & P. cacticida & LMG 2720 & Arizona United States & Carnegiea gigantea & - \\
\hline 19 & Erwinia rhapontici & LMG $2688^{\mathrm{T}}$ & United Kingdom & Rheum rhabarbarum & - \\
\hline 20 & E. persicina & KACC $10053^{\mathrm{T}}$ & Japan & Tomato & - \\
\hline 21 & E. tracheiphila & KACC $10084^{\mathrm{T}}$ & United States & Cucumis melo & - \\
\hline 22 & E. chrysanthemi & KACC $10062^{\mathrm{T}}$ & United States & Chrysanthemum morifolium & - \\
\hline 23 & E. herbicola & LMG 2565 & Canada & Cereals & - \\
\hline 24 & E. nigrifluence & LMG $2694^{\mathrm{T}}$ & Zimbabwe & Knee laceration & - \\
\hline 25 & Enterobacter agglomerans & LMG $1286^{\mathrm{T}}$ & United States & Juglans regia, bark canker & - \\
\hline 26 & Pantoea ananatis & LMG 2676 & United States & Puccinia graminis f. sp. tritici, uredia & - \\
\hline 27 & Xanthomonas oryzae pv. oryzae & KACC 10331 & Republic of Korea & $\ldots$ & - \\
\hline 28 & Pseudomonas syringae pv. syringae & LMG 5082 & United Kingdom & Zea mays & - \\
\hline 29 & P. fuscovaginae & LMG $2158^{\mathrm{T}}$ & Japan & Oryza sativa & - \\
\hline 30 & P. graminis & KACC $10803^{\mathrm{T}}$ & Germany & Grasses & - \\
\hline 31 & Rhizobium radiobacter & KACC 10736 & $\ldots$ & Malus sp. & - \\
\hline 32 & Ralstonia solanacerum & KACC $10814^{\mathrm{T}}$ & United States & Lycopersicon esculentum & - \\
\hline 33 & Serratia marcescens & KACC $11961^{\mathrm{T}}$ & Czech Republic & Pond water & - \\
\hline 34 & Escherichia coli & LMG $2092^{\mathrm{T}}$ & Denmark & Urine & - \\
\hline
\end{tabular}

a Superscript "T" indicates type strain.

${ }^{\mathrm{b}}$ Conventional or real-time assay; + and - indicate species detected or not detected, respectively. 
be amplified with the designed primer set revealed no significant matches in both BLASTn and BLASTx searches.

Specificity test of primers. The PW7011F/R primers were tested against five strains of Pectobacterium wasabiae. As expected, the 140-bp gene fragment was amplified. All other strains, including other Pectobacterium spp., did not amplify with the primer set (Fig. 1).
Sensitivity test by SYBR Green qPCR. We used SYBR Green qPCR assay of $P$. wasabiae with the $\mathrm{PW} 7011 \mathrm{~F} / \mathrm{R}$ primers to generate a standard curve by plotting the mean threshold cycle $(\mathrm{Ct})(n=$ 3 ) versus the logarithmic concentration of genomic DNA, cloned DNA, and density of the bacterial cells (range of $5 \times 10^{0}$ to $5 \times 10^{-6}$ $\mathrm{ng} / \mu \mathrm{l}, 1.45 \times 10^{9}$ to $1.45 \times 10^{3}$ copies $/ \mu \mathrm{l}$, and $3.0 \times 10^{5}$ to $3.0 \times 10^{0}$ $\mathrm{CFU} / \mu \mathrm{l}$, respectively; Fig. 2; Table 2). Standard regression analysis

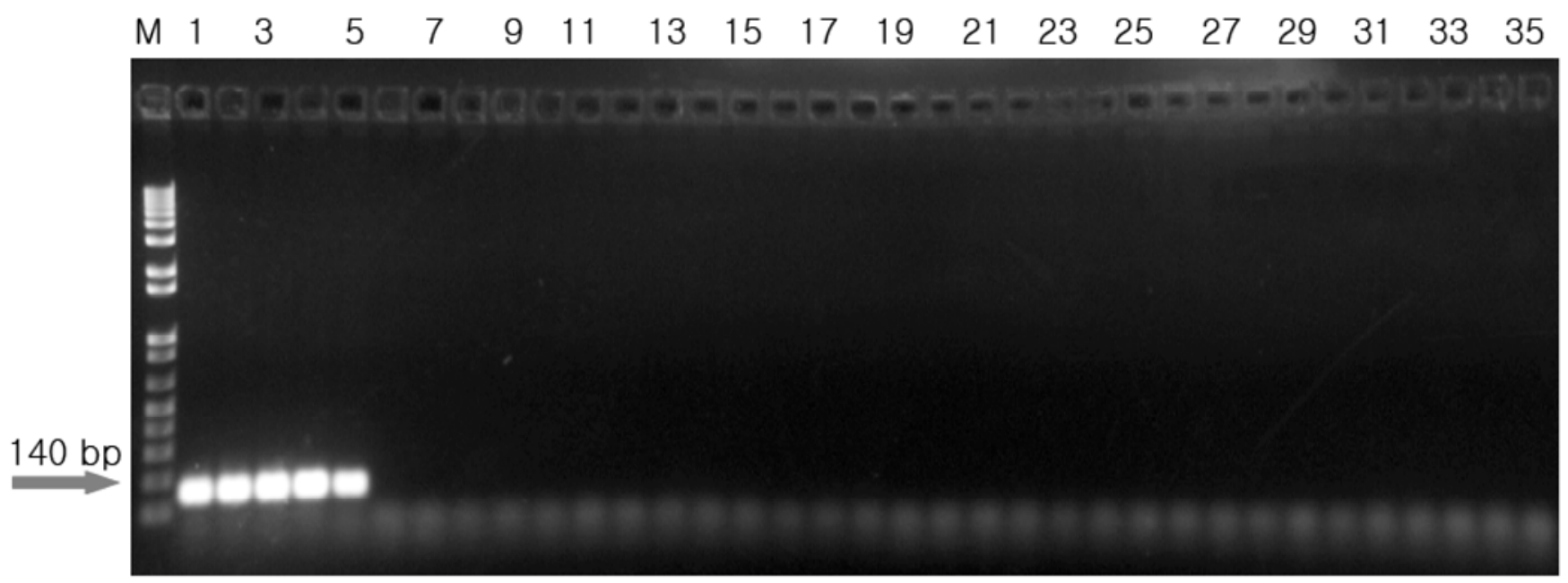

Fig. 1. Specific polymerase chain reaction amplification of a YD repeat protein from Pectobacterium wasabiae with the primer set PW7011F/R. Lane M is the size marker (1kb DNA plus ladder; Gibco BRL) while lanes 1-5 were $P$. wasabiae strains; lanes 6-34 included strains from other Pectobacterium spp. along with strains from species of Erwinia, Pantoea, Xanthomonas, Pseudomonas, Rhizobium, Ralstonia, Serratia, and Escherichia; and lane 35 was a negative control (distilled water).
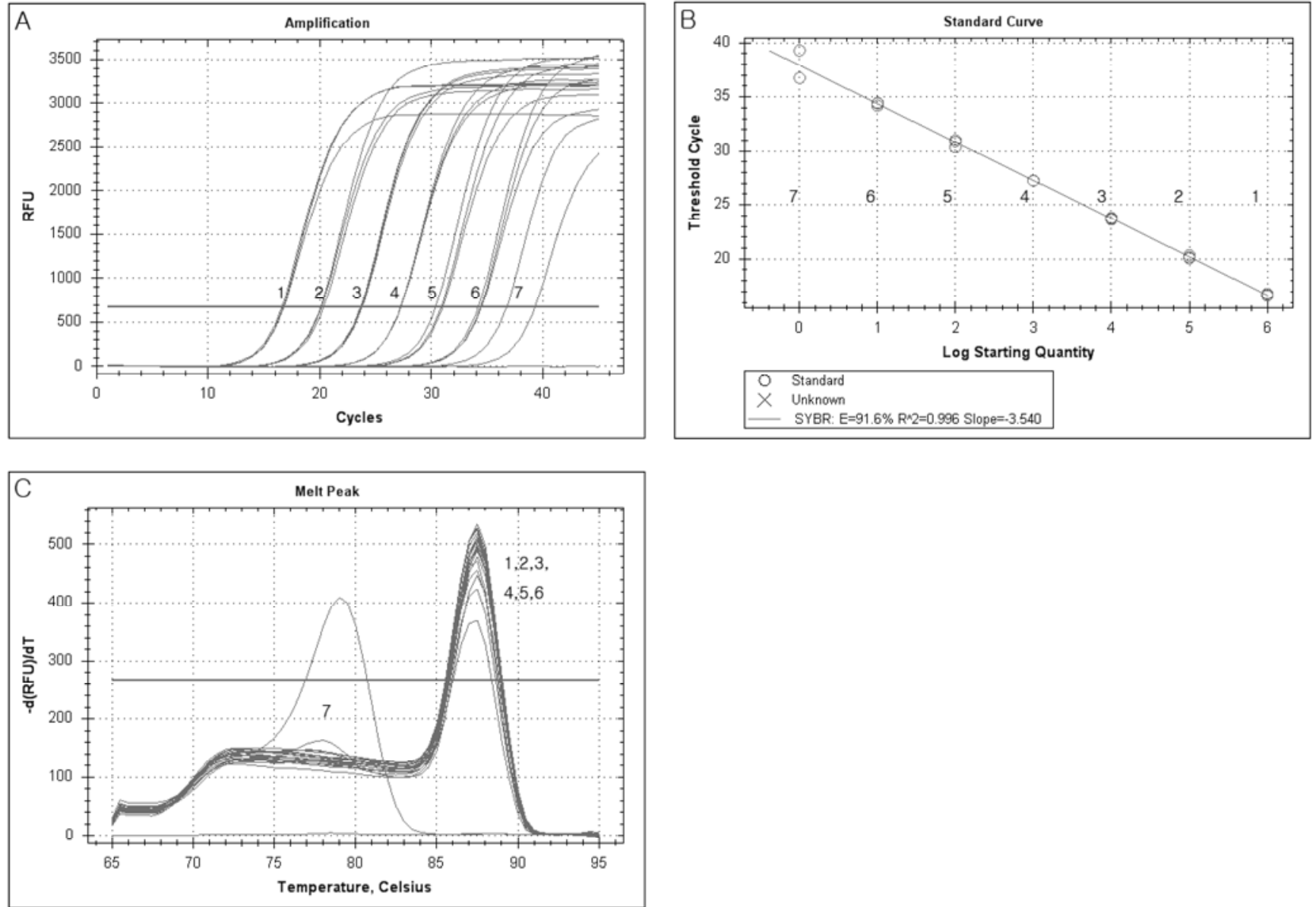

Fig. 2. Real-time polymerase chain reaction (PCR) with SYBR Green and primers PW7011F/R for quantitative amplification of Pectobacterium wasabiae LMG8444. A, Fluorescence signal in relation to the amount of template. For each assay, cloned amplified target DNA using purified DNA $\left(5 \times 10^{0} \mathrm{ng} / \mathrm{\mu l}\right)$ was diluted 10 -fold (sample numbers 1-7) and used as a template in the PCR. B, Standard curve derived from amplification plot shown in A. C, Melting-curve analysis is shown as the negative first derivative of the relative fluorescence units $\left(-\mathrm{d}(\mathrm{RFU}) / \mathrm{dT}\right.$ ) plotted versus temperature; (primer dimer product: $79.0^{\circ} \mathrm{C}$, amplified product: $87.5^{\circ} \mathrm{C}$ ). 
of the linear part of the slope gave a coefficient of -3.540 , which yielded a PCR efficiency of $91.6 \%$ (Fig. 2B). Analysis of the melting temperature and melting peaks of $P$. wasabiae by SYBR Green qPCR revealed a reproducible melting temperature of $87^{\circ} \mathrm{C}$ and specific peaks (Fig. 2C).

A sensitivity test was performed using 10-fold dilution series of genomic DNA and bacterial suspension of $P$. wasabiae. The minimum detection level of genomic DNA and bacterial suspension by SYBR Green qPCR assay was approximately $5 \times 10^{0} \mathrm{fg} / \mu \mathrm{l}$ and 3 CFU/reaction of $P$. wasabiae, respectively. Standard curves showed

Table 2. Mean threshold cycle (Ct), end-point fluorescence, and 10-fold serially diluted Pectobacterium wasabiae LMG8444 genomic DNA and bacterial suspensions by SYBR-Green quantitative polymerase chain reaction ${ }^{\mathrm{a}}$

\begin{tabular}{lcccc}
\hline Genomic DNA & & & \multicolumn{2}{c}{ Bacterial suspensions } \\
\cline { 1 - 2 } \cline { 4 - 5 } $\mathbf{n g} / \boldsymbol{\mu l}$ & Ct values & & CFU/ $\boldsymbol{\mu l}$ & Ct values \\
\hline $5 \mathrm{ng}$ & $16.45 \pm 0.25$ & & $\mathrm{ND}$ & $\mathrm{ND}$ \\
$500 \mathrm{pg}$ & $19.29 \pm 0.16$ & & $3.0 \times 10^{5}$ & $24.45 \pm 0.26$ \\
$50 \mathrm{pg}$ & $22.49 \pm 0.10$ & & $3.0 \times 10^{4}$ & $23.94 \pm 0.16$ \\
$5 \mathrm{pg}$ & $26.16 \pm 0.17$ & & $3.0 \times 10^{3}$ & $26.62 \pm 0.29$ \\
$500 \mathrm{fg}$ & $29.50 \pm 0.29$ & & $3.0 \times 10^{2}$ & $30.13 \pm 0.11$ \\
$50 \mathrm{fg}$ & $33.14 \pm 0.11$ & & $3.0 \times 10^{1}$ & $33.69 \pm 0.24$ \\
$5 \mathrm{fg}$ & $36.11 \pm 0.19$ & & $3.0 \times 10^{0}$ & $36.59 \pm 0.52$ \\
\hline
\end{tabular}

${ }^{\mathrm{a}} \mathrm{ND}=$ not determined.
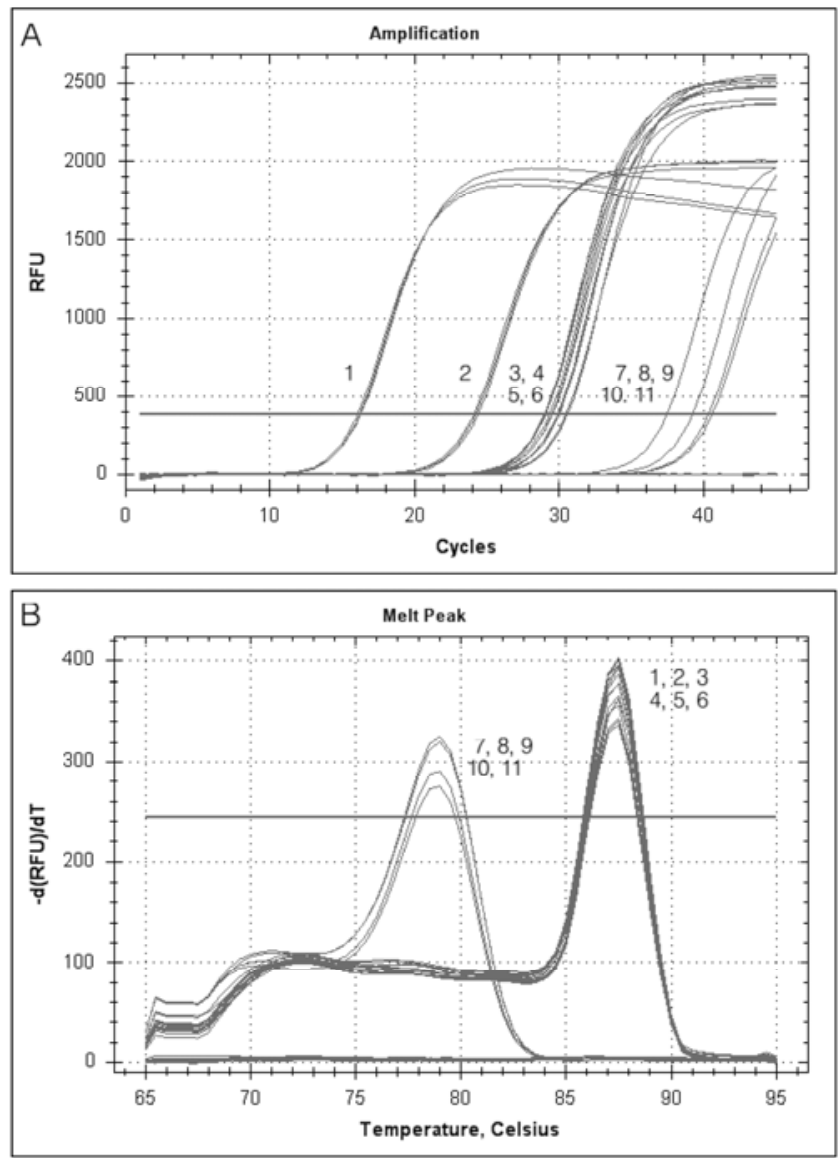

Fig. 3. Specific detection of Pectobacterium wasabiae by SYBR Green biopolymerase chain reaction in infected leaves using the primer set PW7011F/R. A, Fluorescence intensity corresponding to a YD repeat protein from Pectobacterium wasabiae amplified using PW7011F/R. Sample 1, P. wasabiae LMG8444 genomic DNA; sample 2, $P$. wasabiae LMG8444 cell suspension (optical density at $600 \mathrm{~nm}=$ 0.1 ); samples 3-6, infected wasabi leaves; samples 7-11, healthy wasabi leaves and no template control). B, Melting curve analysis generated during polymerase chain reaction. Amplified products derivative of relative fluorescence units $(-\mathrm{d}(\mathrm{RFU}) / \mathrm{dT})$ is plotted as a function of temperature (primer dimer product: $79.0^{\circ} \mathrm{C}$, amplified product: $87.5^{\circ} \mathrm{C}$ ). that there was a linear correlation between the $\mathrm{Ct}$ values and the concentrations of input DNA $\left(R^{2}=0.998\right.$, slope $\left.=-3.346\right)$ or cell suspension $\left(R^{2}=0.995\right.$, slope $\left.=-3.235\right)$ of the pathogen. A standard curve for density of the cell suspension was generated, except for $3.0 \times 10^{5} \mathrm{CFU} / \mu \mathrm{l}$, due to an overlap between $3.0 \times 10^{5}$ and 3.0 $\times 10^{4} \mathrm{CFU} / \mu \mathrm{l} \mathrm{Ct}$ values (Table 2 ).

Detection of pathogen by bio-PCR. The primer set PW7011F/R could also detect the $P$. wasabiae by SYBR Green PCR in four symptomatic wasabi leaves. Amplified products derived from all symptomatic samples showed fluorescence in the SYBR Green PCR assay, and the expected DNA fragment of 140 bp was amplified by SYBR Green PCR, whereas no amplicons were obtained from healthy leaves. The $\mathrm{Ct}$ values of cell suspensions $\left(\mathrm{OD}_{600}=0.1\right)$ ranged from 24.10 to 24.38 , whereas the $\mathrm{Ct}$ values of inoculated samples ranged from 28.26 to 30.55 (Fig. 3).

\section{Discussion}

The primary hurdle in developing specific, easily used diagnostic markers for any pathogenic bacteria has been the difficulty in finding unique features whether they are bacterial surface antigens or gene sequences. Rapid detection and accurate identification of pathogens is important to guide responses for the prevention or elimination of plant pathogens. In particular, early disease detection is necessary for assessing the health status of plants before the transplantation of seedlings to fields.

The molecular assay for identification of Pectobacterium (formerly Erwinia) spp. is often difficult and controversial. The analyses of $16 \mathrm{~S}$ rRNA gene, $g y r B$, and $r p o D$ are very widely used for the molecular identification of bacteria. However, these regions do not sufficiently distinguish between the closely related species of Pectobacterium $(6,9)$. In this study, we developed a primer set for the specific detection of $P$. wasabiae using available genome sequence information in GenBank. The species-specific primers derived from the whole genome sequences of $P$. wasabiae WPP163 (GenBank accession CP001790.1). The YD repeat protein gene sequence (GenBank accession ACX86200.1) was analyzed by blast searches and identified to be highly variable among Pectobacterium spp. The YD repeat proteins (Rhs repertoires) are very dynamic among enterobacterial genomes, because of gains and losses in the repeated gene. In contrast, the main structures of $R h s$ genes are evolutionarily conserved, indicating that $R h s$ sequence diversity is driven not by rapid mutation but by the relatively slow evolution of novel core-tip combinations. Nevertheless, the function of these proteins is still unknown and the conditions under which they are expressed have also been difficult to define (8).

Therefore, a SYBR Green qPCR assay for the detection of $P$. wasabiae based on the YD repeat protein was developed in this study. In general, when cell suspensions or tissue extracts are directly used for a PCR, the appearance of nonspecific amplification bands is a common problem, which hampers the interpretation of the results (14). However, no spurious bands were observed in any of the samples analyzed using the PW7011F/R primer set, indicating that the primer set is very specific to $P$. wasabiae and reliable for the detection and identification of this pathogen. This method is faster and more economical and practical than the traditional methods.

\section{Acknowledgments}

This study was carried out with the support of the Research Program for Agricultural Science and Technology Development, National Academy of Agricultural Science, Rural Development Administration, Republic of Korea.

\section{Literature Cited}

1. Atlas, R. M. 2004. Handbook of Microbiological Media, 3rd ed. CRC Press, Boca Raton, FL.

2. Feulner, G., Gray, J. A., Kirschman, J. A., Lehner, A. F., Sadosky, A. B., Vlazny, D. A., Zhang, J., Zhao, S., and Hill, C. W. 1990. Structure of the rhsA locus from Escherichia coli K-12 and comparison of rhsA with other members of the rhs multigene family. J. Bacteriol. 172:446-456.

3. Forde, B. 1987. Report to the Minister of Science and Technology on DSIR visit to Buller. Department of Scientific and Industrial Research Discussion Paper Number 7. Wellington, New Zealand.

4. Fu, J., Li, D., Xia, S., Song, H., Dong, Z., Chen, F., Sun, X., and Tang, Z. 
2009. Absolute quantification of plasmid DNA by real-time PCR with genomic DNA as external standard and its application to a biodistribution study of an HIV DNA vaccine. Anal. Sci. 25:675-680.

5. Gardan, L., Gouy, C., Christen, R., and Samson, R. 2003. Elevation of three subsp. of Pectobacterium carotovorum to species level: Pectobacterium atrosepticum sp. nov., Pectobacterium betavasculorum sp. nov. and Pectobacterium wasabiae sp. nov. Int. J. Syst. Bacteriol. 53:381-391.

6. Gardan, L., Shafif, H., and Grimont, P. A. D. 1997. DNA relatedness among pathovars of Pseudomonas syringae and related bacteria. Pages 445-448 in: Pseudomonas syringae Pathovars and Related Pathogens. K. Rudolph, T. J. Burr, J. W. Mansfield, D. Stead, J. Von Kietzell, and A. Vivian, eds. Kluwer Academic Publishers, London.

7. Goto, M., and Matsumoto, K. 1987. Erwinia carotovora subsp. wasabiae subsp. nov. isolated from diseased rhizomes and fibrous roots of Japanese horseradish (Eutrema wasabi Maxim.). Int. J. Syst. Bacteriol. 37:130-135.

8. Jackson, A. P., Thomas, H. T., Parkhill, J., and Thomson, N. R. 2009. Evolutionary diversification of an ancient gene family (rhs) through Cterminal displacement. BMC Genomics. 10:584

9. Kwon, S. W., Go, S. J., Kang, H. W., Ryu, J. C., and Jo, J. K. 1997. Phylogenetic analysis of Erwinia species based on 16S rRNA gene sequences. Int. J. Syst. Bacteriol. 47:1061-1067.

10. Lee, Y. S., Yang, J. H., Bae, M. J., Yoo, W. K., Ye, S., Xue, C. L., and Li, C. G. 2010. Anti-oxidant and anti-hypercholesterolemic activities of Wasabia japonica. eCAM 7:459-464.

11. Made, D., Petersen, R., Trumper, K., Stark, R., and Grohmann, L. 2004. Inhouse validation of a real-time PCR method for rapid detection of Salmonella ssp. in food products. Eur. Food Res. Technol. 219:171:177.

12. Maeda, Y., Shinohara, H., Kiba, A., Ohnishi, K., Furuya, N., Kawamura, Y., Ezaki, T., Vandamme, P., Tsushima, S., and Hikichi, Y. 2006. Phylogenetic study and multiplex PCR-based detection of Burkholderia plantarii, Burkholderia glumae and Burkholderia gladioli using gyrB and $r p o D$ sequences. Int. J. Syst. Evol. Microbiol. 56:1031-1038.

13. Minet, A. D., Rubin, B. P., Tucker, R. P., Baumgartner, S., and ChiquetEhrismann, R. 1999. Teneurin-1, a vertebrate homologue of the Drosophila pair-rule gene ten-m, is a neuronal protein with a novel type of heparinbinding domain. J. Cell Sci. 112:2019-2032.

14. Park, D. S., Shim, J. K., Kim, J. S., Kim, B. Y., Kang, M. J., Seol, Y. J., Hahn, J. H., Shrestha, E., Lim C. K., Go, S. J., and Kim, H. G. 2006. PCRbased sensitive and specific detection of Pectobacterium atrosepticum using primers based on Rhs family gene sequences. Plant Pathol. 55:625-629.

15. Park, H. K., Lee, H. J., Jeong, E. G., Shin, H. S., and Kim, W. 2010. The rgg gene is a specific marker for Streptococcus oralis. J. Dent. Res. 89:1299-1303.

16. Pitman, A. R., Harrow, S. A., and Visnovsky, S. B. 2009. Genetic characterisation of Pectobacterium wasabiae causing soft rot disease of potato in New Zealand. Eur. J. Plant Pathol. 129:413-425.

17. Rose, P., Harkin, J. M., and Hickey, W. J., 2003. Competitive touchdown PCR for estimation of Escherichia coli DNA recovery in soil DNA extraction. J. Microbiol. Methods 52:29-38.

18. Sultana, T., and Savageb, G. P., 2008. Wasabi-Japanese horseradish. Bangladesh J. Sci. Ind. Res. 43:433-448

19. Suzuki, H. 1976. Ecology and control of the major diseases of wasabi plants. Shokubutsu Boeki 30:34-38.

20. Van Doorn, H. R., Claas, E. C., Templeton, K. E., van der Zanden, A. G., te Koppele Vije, A., de Jong, M. D., Dankert, J., and Kuijper, E. J. 2003. Detection of a point mutation associated with high-level isoniazid resistance in Mycobacterium tuberculosis by using real-time PCR technology with 3'minor groove binder-DNA probes. J. Clin. Microbiol. 41:4630-4635. 